\title{
MEMBUAT SENYUM BAHAGIA DENGAN BERBAGI BINGKISAN LEBARAN UNTUK ANAK YATIM DAN DHUAFA
}

\author{
${ }^{1}$ Nopi Oktavianti, ${ }^{2}$ Syarifah Ida Farida, ${ }^{3}$ R. Chepi Safei Jumhana, \\ ${ }^{4}$ Aod Abdul Jawad, ${ }^{5}$ Aprilia Astuti \\ Universitas Pamulang \\ Email : 1 octavianti24@gmail.com
}

Manuskrip: Okt-2020; Ditinjau: Nov -2020; Diterima: Des -2020; Online: Jan-2021; Diterbitkan: Jan-2021

\begin{abstract}
ABSTRAK
Kegiatan Pengabdian Kepada Masyarakat ini bertujuan dalam rangka menyambut hari raya Idul Fitri1441 hijriyah dan untuk meringankan sedikit beban para kaum dhuafa serta memberikan sedikit kebahagiaan dan senyuman kepada para anak yatim dengan memberikan bantuan berupa pangan (sembako) dan bingkisan Lebaran, khususnya bagi anak yatim dan kaum dhuafa di daerah Kecamatan Parung Panjang Bogoryang terkena dampak ekonomi secara langsung akibat wabah Covid-19. Dana yang terkumpul dari donasi para dosen Fakultas Ekonomi ini kemudian disalurkan melalui LAZ Nahwa Nur yang bertempat di Cibinong - Jawa Barat.

Hasil kegiatan PKM menunjukan bahwa permasalahan mitra yang merupakan para anak yatim dan kaum dhuafa di Kecamatan Parung Panjang Bogor, dengan adanya pandemic covid 19 yang mengakibatkan mereka tidak mendapatkan penghasilan seperti pedagang kecil, informal, ojol dan supir. Kami berinisiatif membantu program pemerintah dalam meringankan beban masyarakat khususnya masyarakat menengah kebawah yang sangat terpengaruh dengan adanya wabah covid 19 ini, dengan memberikan bantuan sembako sebagai bingkisan idul fitri untuk meringankan beban saudara kita yang terkena dampak virus corona khususnya para anak yatim dan kaum dhuafa. Dengan ini, tentunya akan dapat membantu masyarakat yang memang membutuhkan, yang susah mencari rejeki pada saat wabah covid 19 ini menimpa kita semua.

Metode kegiatan yang digunakan adalah melakukan kerjasama dengan Laz Nahwa Nur lalu kami melakukan survey untuk menggalang dana untuk para anak yatim dan kaum dhuafa yang membutuhkan. Setelah kami mendapatkan data orangorang yang ada diperkampungan yang membutuhkan bantuan dikarenakan tidak mendapatkan penghasilan. Setelah survey dilakukan maka ditentukan lokasi pelaksanaan dan sasaran yang benar-benar membutuhkan bantuan. Adapun data yang kami dapatkan dari beberapa daerah di Parung Panjang kami telah mendistribusikan ke orang-orang yang benar-benar membutuhkan bantuan.
\end{abstract}

Kata kunci : Covid-19, Lebaran, Kaum Dhuafa 


\section{PENDAHULUAN}

Pada awal tahun 2020 ditandai dengan merebaknya wabah covid 19 membuat negara termasuk masyarakatnya sendiri mengalami kepanikan massal. Dalam kondisi demikian beberapa negara salah satunya Indonesia. Sejak adanya covid-19 membuat pemerintah Indonesia mengeluarkan kebijakan berupa mengajak masyarakat untuk melakukan sosial distancing atau physical distancing, menutup beberapa toko atau rumah-rumah makan dan hanya berdiam diri dirumah dengan harapan dapat memutus rantai virus covid-19.

Hal ini berdampak pada roda perekonomian negara Indonesia yang berimbas kepada perekonomian masyarakat kecil kebawah dimana untuk memenuhi kebutuhan sehari-hari masyarakat para pelaku usaha kecil menengah harus tetap berjualan dengan adanya covid-19 yang bisa membahayakan kesehatan mereka. Padahal UKM tersebut merupakan pondasi perekenomian masyarakat kebawah. Datangnya wabah covid-19 mematikan perekenomian pelaku usaha kecil menengah kebawah dan akan berdampak pada tingkat kesejahteraan masyarakat.

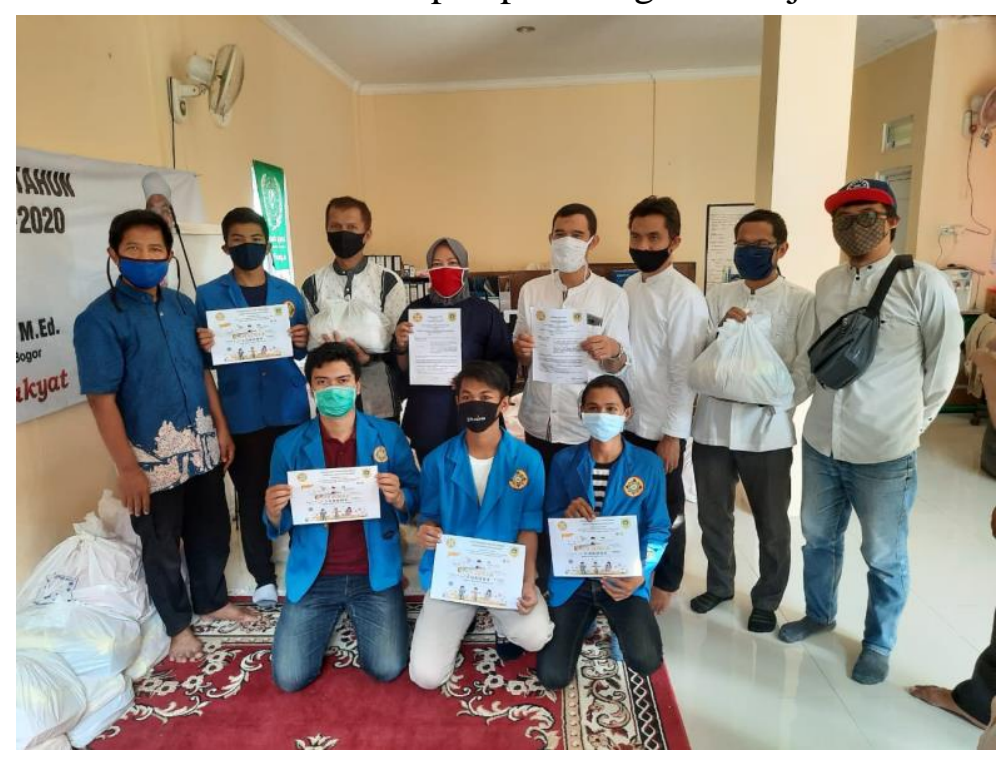

Gambar 1. Foto bersama anggota PKM

\section{METODE PELAKSANAAN KEGIATAN}

Metode kegiatan yang digunakan dalam kegiatan ini yaitu memberikan bantuan berupa pangan (sembako) sebagai bingkisan idul fitri $1441 \mathrm{H}$. Program Pengabdian Kepada Masyarakat di Kecamatan Parung Panjang Bogor ini bagi menjadi 3 tahapan, tahap pertama persiapan yaitu survey lapangan dan penyusunan bahan materi, tahap kedua pelaksanaan, yaitu pemberian bantuan, tahap ketiga evaluasi. Berikut adalah bagan alur dari setiap rangkaian kegiatan.

1) Tahap Persiapan

2) Tahap Pelaksanaan 
Tahap Evaluasi, pada tahap evaluasi ini untuk mengetahui seberapa berhasilkah kegiatan berbagi bingkisan kepada anak yatim dan kaum dhuafa di Kecamatan Parung Panjang Bogor, yakni melalui apakah kegiatan berjalan lancar sehingga masyarakat penerima dapat merasakan manfaatnya dengan sebaik mungkin. Evaluasi ini penting sebagai tahap monitoring apakah PKM yang telah kita lakukan sudah berhasil atau belum.

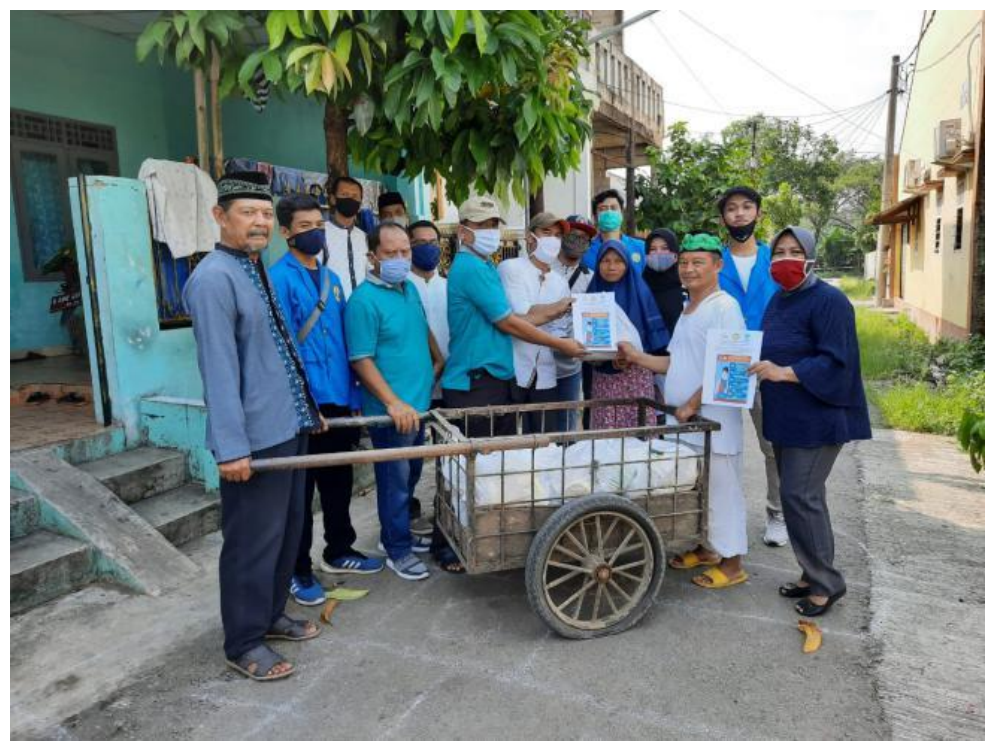

Gambar 2. Foto Kegiatan PKM

\section{HASIL DAN PEMBAHASAN}

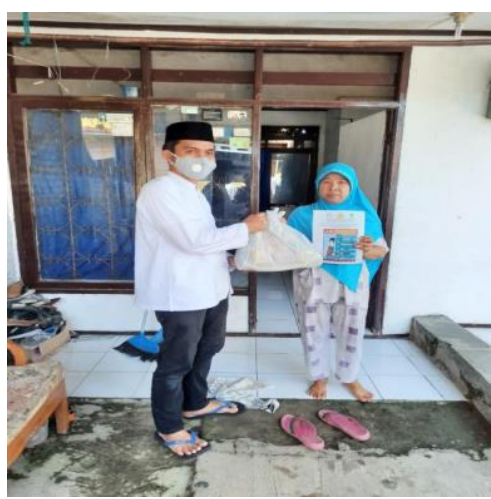

Gambar 3. Foto pemberian Bantuan PKM

Langkah awal metode pelaksanaan kegiatan pengabdian ini yaitu kami melakukan kerjasama dengan Lembaga Amil Zakat yang berfokus pada pemberdayaan dan pembinaan masyarakat dhuafa dalam mengentaskan kemiskinan melalui aktivitas penghimpunan, penyaluran dan pembedayaan dana zakat, infaq, shodaqoh serta dana sosial lainnya. LAZ NAHWA NUR merupakan yayasan yang sudah banyak berkontribusi dan berkiprah dimasyarakat baik dibidang pendidikan, sosial, ekonomi, kemanusiaan dan juga dakwah.

Kegiatan pengabdian kepada masyarakat ini dimulai dengan penggalangan dana para dosen Manajemen Universitas Pamulang, kemudian kami memberikan donasi kepada LAZ NAHWA NUR untuk didistribusikan kepada anak yatim dan kaum dhuafa yang terkena dampak covid19 dan bantuan tersebut dibelikan sembako berupa bingkisan idul fitri yang mereka butuhkan. Melalui media sosial, dana yang terkumpul kami berikan dan diserahkan melalui transfer ke rekening LAZ NAHWA NUR dan langsung dibelikan untuk 
segera didistribusikan kepada yang membutuhkan. Selain itu, LAZ NAHWA NUR juga membantu dalam menggiatkan UKM dengan mengajak mereka bergabung dalam UMKM yang ada disekitar mereka. Sehingga ada pemasukan dan pengalaman yang baru dalam mendapatkan penghasilan yang halal dan thoyib. Untuk lebih jelasnya, tahapan kegiatan PKM ini dapat dijelaskan melalui gambar berikut ini :

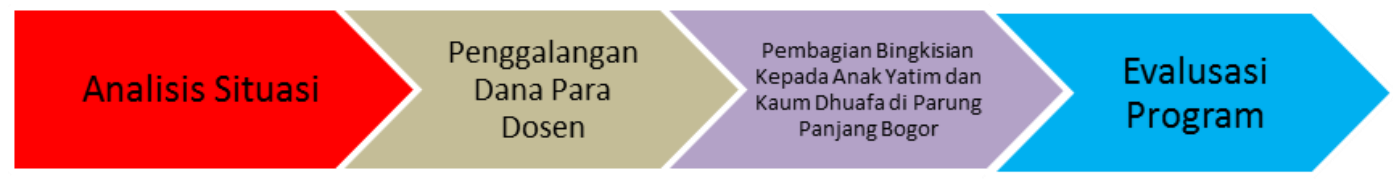

Gambar 4 : Tahapan Kegiatan PKM

Luaran yang diharapkan dalam program ini adalah membantu program pemerintah dalam meringankan beban masyarakat khususnya masyarakat menengah kebawah yang sangat terpengaruh dengan adanya wabah covid-19 ini, dengan memberikan bantuan sembako sebagai bingkisan idul fitri $1441 \mathrm{H}$ khususnya para anak yatim dan kaum dhuafa. Selain itu kami memberikan masukan kepada LAZ NAHWA NUR untuk mengurangi angka kemiskinan melalui pemberdayaan masyarakat dengan memberikan pelatihan keterampilan dibidang strategis yang dibutuhkan oleh perusahaan atau masyarakat. Pelatihan tersebut dirancang agar warga binaan tersebut dapat mengetahui gambaran keterampilan dari mulai teori dasar, praktek dan peluang bekerja dibidang tersebut.

Mengacu pada identifikasi permasalahan tersebut, maka Ada beberapa strategi pemberdayaan masyarakat yang bisa menjadi pilihan dalam melaksanakan pemberdayaan masyarakat antara lain :

Strategi dengan tiga pendekatan, yaitu :

1. Pendekatan Mikro

2. Pendekatan Mezzo

3. Pendekatan Makro

Strategi dengan 5P, menurut Suharto dalam Oos M. Anwas 30 yaitu : pemungkinan, penguatan, perlindungan, penyokongan dan pemeliharaan.

\section{KESIMPULAN DAN SARAN}

Dengan terlaksananya kegiatan pengabdian kepada masyarakat dengan memberikan bantuan sembako berupa bingkisan idul fitri kepada anak yatim dan kaum dhuafa yang terkena dampak covid-19 kami mengucapkan rasa syukur kepada Tuhan Yang Maha Esa, sehingga kegiatan ini berjalan dengan yang kita harapkan. Begitu juga terima kasih kepada seluruh pihak yang turut serta dalam pelaksanaan kegiatan ini.

Hal yang dapat kami simpulkan, bahwa manusia pada hakikatnya adalah makhluk sosial dimana kita saling membutuhkan. Meringankan sedikit beban saudara-saudara kita merupakan suatu kewajiban bagi kita yang mampu, bukan acuh atau menghardik dengan cemohan-cemohan yang tidak baik. Mari datangi dan kasihi dengan mendengarkan orang-orang yang berada dibawah kita, sehingga kita 
bisa merasakan, menempatkan diri kita ketempat yang saat ini mereka rasakan. Setelah itu kita tidak hanya duduk melihat tapi mengulurkan tangan memberi dan mengasihi suadara-saudara disekeliling kita.

\section{DAFTAR PUSTAKA}

Ajimat, A., Sunarsi, D., \& Sidiq, F. (2020). Berwirausaha Memanfaatkan Media Sosial Pada Daerah Sepatan. ADI Pengabdian Kepada Masyarakat, 1(1), 69-76.

Keputusan Presiden Republik Indonesia Nomor 11 tahun 2020 Tentang penetapan kedaruratan kesehatan masyarakat corona virus disease 2019 (covid-19)

Pasal 4 ayat (1) Undang- Undang Dasar Negara Repubik Indonesia Tahun 1945

Peraturan Gubernur Nomor 27 tahun 2020 tentang Pedoman PSBB

Peraturan Pemerintah Republik Indonesia Nomor 21 Tahun 2020 Tentang Pembatasan Sosial Berskala Besar Dalam Rangka Percepatan Penanganan Corona Virus Disease 2019 (covid-19)

Rahmi Hermawati, Listya Sugiyarti, Rima Handayani, Denok Sunarsi, Siti Alfiah, Ali Maddinsyah. (2020). The Effect of Trilogy Leadership Style and Organization Culture on School Performance: Evidence form Indonesian Senior High School . PalArch's Journal of Archaeology of Egypt / Egyptology, 17(6), $8512 \quad$ - 8537. Retrieved from http://www.palarch.nl/index.php/jae/article/view/2261

UU No.6 Tahun 2018 tentang Karantina Kesehatan (Lembaga Negara Republik Indonesia Tahun 2018 Nomor 128, Tambahan Lembaran Negara Republik

Website : Indonesia Nomor 6236);

https://irto.id/pertumbuhan-ekonomi-minus-catatan-buruk-krisis-ekonomi-ri9798-eKbR

Jurnal.id (2019, Maret 12). Retrieved from https://jurnal.id:https://www.jurnal.id/id/blog/strategi-bisnis-untukbersaing 